\title{
Islet Antigen 2 Autoantibody Measurement
}

National Cancer Institute

\section{Source}

National Cancer Institute. Islet Antigen 2 Autoantibody Measurement. NCI Thesaurus.

Code C135429.

The determination of the amount of antibody to endogenous islet antigen 2 in a biological sample. 